\title{
Economic Determinants of Foreign Direct Investment in India
}

\author{
M. Arul Provin Binny, A. Morarji
}

\begin{abstract}
Foreign direct investment is an investment made by a firm or individual in one country into business interests located in another country. It is one of the most interesting topics in the area of international business and trade. Foreign companies invest directly in fast growing private Indian businesses to take benefits of India. The foreign investors mostly from the urbanized dynamic centers are enhancing international production by investing in resource abundant economies. This shows substantial differences in specifications with little agreement on the set of covariates that are included. The main objective of this FDi are To examine the policy framework of India in relation to foreign direct investment and to analyze the trends and patterns of foreign direct investment in India and to assess the present position of FDI in India This paper empirically attempted to investigate the determinants of foreign direct investment in India. This paper investigates the role of economic structures as determinants of foreign direct investment inflows. The exports has been emerged the most powerful determinant of FDI. This article is to understand the extent to which well functioning economic structures are important drivers of FDI inflows into advanced countries. The Various factors which play a significant role in attracting FDI into a particular state are also examined. It is an appealing concept through which companies progress and enter into new markets as a result of globalization. It has grown that the academic and policymaking worlds have struggled to keep up with the expanding incident. FDI is an engine of economic growth and development of Indian economy but in this respect proper directions are needed to improve the quality of the Indian economy as a whole.
\end{abstract}

Keywords: Features of FDI, Economic, Growth of FDI, Advantages.

\section{INTRODUCTION}

The term "Foreign Direct Investment," or "FDI," encompasses two related but different sets of topics or activities, explained by different theories and by different branches of economics. The first might be referred to as the international finance, or macro, view. The second might be referred to as the industrial organization, or micro, view. Foreign direct investment (FDI) in India is a major monetary source for economic development in India. Foreign companies invest directly in fast growing private Indian businesses to take benefits of

Revised Manuscript Received on October 15, 2019.

* Correspondence Author

M.Arul Provin Binny, PhD Scholar (Part-time), Alagappa Institute of Management (AIM), Alagappa University, Karaikudi, Tamilnadu, India.

Dr.A. Morarji, Professor, Department of Corporate Secretaryship, Alagappa University, Karaikudi, Tamilnadu, India.

cheaper wages and changing business environment of India. The main objective of this FDi are To examine the policy framework of India in relation to foreign direct investment and to analyze the trends and patterns of foreign direct investment in India and to assess the present position of FDI in India. Economic liberalization started in India in wake of the 1991 economic crisis and since then FDI has steadily increased in India, which subsequently generated more than one crores (10 million) jobs.

Many policy makers and academics contend that foreign direct investment (FDI) can have important positive effects on a host country's development effort.1 In addition to the direct capital financing it supplies, FDI can be a source of valuable technology and know-how while fostering linkages with local firms, which can help jumpstart an economy. Based on these arguments, industrialized and developing countries have offered incentives to encourage foreign direct investments in their economies. The foreign investments are complementary to economic growth and development in developing countries like India. Investment in an economy raises output and improves standard of living of the people. In an effort to further examine the effects of FDI on economic growth; this research explores the roles different types of FDI have played in different sectors.

\section{ECONOMICAL GROWTH IN FDI}

The historical background of FDI in India can be traced back with the establishment of East India Company of Britain. British capital came to India during the colonial era of Britain in India. After Second World War, Japanese companies entered Indian market and enhanced their trade with India, yet U.K. remained the most dominant investor in India. Further, after Independence issues relating to foreign capital, operations of MNCs, gained attention of the policy makers. Keeping in mind the national interests the policy makers designed the FDI policy which aims FDI as a medium for acquiring advanced technology and to mobilize foreign exchange resources. With time and as per economic and political regimes there have 
been changes in the FDI policy too. The industrial policy of 1965, allowed MNCs to venture through technical collaboration in India. Therefore, the government adopted a liberal attitude by allowing more frequent equity.

Activities that create by FDI also lead to productivity and knowledge spill over on host country domestic firm. Productivity and knowledge spill over is arise when the productivity of locally owned firm is gain through access to the advance leading edge of technologies employed by foreign companies. However, there are some arguments on this matter. As the foreign presences were in greater level, the negative impacts were start to apparent. These foreign companies have ability in draw the demand away from local counterpart due to the price reduction to their new differentiated and innovation products. As a result, local firm productiveness will fall because of "market stealing" activity run by foreign affiliates.

\section{Salient Features of FDI}

- FDI up to 100 per cent is allowed under the automatic route in all activities/sectors except the following, which will require approval of the Government

- Proposals in which the foreign collaborator has a previous or existing venture/tie up in India in the same or allied field.

- All proposals relating to acquisition of shares in an existing Indian company by a foreign or NRI investor.

- All proposals falling outside notified sectoral policy or caps or under sectors in which FDI is not permitted

\section{TYPES OF FDI}

- Equity Capital is defined as buying the shares of an enterprise out of foreign direct investor's own country. This is also called "first investment".

- Profits converted into new investments comprise profits which aren't obtained by the foreign direct investor.

- Internal Debts in Corporation mean that are short or long-termed debt and credit funds between direct investors and tied enterprises at issue.

Developing countries are not able to allocate sufficient resources to the investments that would contribute to the economic development. The main reasons for that are low per capita income, unfair income distribution and high consumption tendency. At this point, foreign capital can fulfill the need for resources to some extent.

\section{Strategic Motives For Direct Foreign INVESTMENT}

Surveys and case studies of international firms indicate that their motivations for making direct foreign investments are based on strategic considerations of five main types, from which the firms may be classed as:

- market seekers

- raw material seekers

- production efficiency seekers

- knowledge seekers

- political safety seekers

\section{AdVANTAGES OF Foreign DIRECT INVESTMENT}

Foreign direct investment benefits the global economy, as well as investors and recipients. Capital goes to the businesses with the best growth prospects, anywhere in the world. Investors seek the best return with the least risk. This profit motive is colour-blind and doesn't care about religion or politics.

That gives well-run businesses, regardless of race, colour, or creed, a competitive advantage. It reduces the effects of politics, cronyism, and bribery. As a result, the smartest money rewards the best businesses all over the world. Their goods and services go to market faster than without unrestricted FDI

- It provides local economic benefits in multiple locations.

- It makes international trade easier to complete.

- Foreign income can increase.

- It improves human resources.

- It allows your money to work harder for you.

- It provides a foreign company with needed experience

- It creates new opportunities for workers.

\section{CONSEQUENCES OF ECONOMIC IMPACT BY FDI}

While there may be attempts to restrict or resist FDI by developing countries, its positive economic impact is undeniable. In terms of the economic impact of FDI to the host developing countries revealed that FDI is indeed good for the economic health of developing countries, regardless of the policy regime, industry, or time period studied. In thirteen out of fourteen case studies, FDI increased productivity and output in the sector, increasing national income while lowering prices and improving quality and selection for consumers. Despite criticisms of the impact of FDI on emerging countries' economies, their research showed that foreign companies paid 
higher wages and were more likely to comply with local labor laws than domestic companies.

In most of the emerging countries studied, the institute saw lower prices and better selection after foreign companies arrived, mainly because they have a tendency to improve the efficiency and productivity of the sector by bringing new capital, technology, and management skills and forcing less efficient domestic companies to either improve their operations or leave. While incumbent companies stand to lose, consumers benefit. Often, lower prices then led to an increase in demand and industry growth.

\section{RESULT AND CONCLUSION}

Foreign Direct Investment is an appealing concept through which companies progress and enter into new markets as a result of globalization. There are many factors that might influence a company's decision to enter into a new market such as the availability of resources, the political stability of the identified country and the nation's openness to regional and international trade. FDI is an engine of economic growth and development of Indian economy but in this respect proper directions are needed to improve the quality, quantity and allocation of FDI in different sectors of the Indian economy as a whole.

\section{REFERENCES}

[1] Laura Alfaro April 2003 Foreign Direct Investment and Growth: Does the Sector Matter

[2] Basu P., Nayak N.C, Archana (2007): "Foreign Direct Investment in India: Emerging

[3] Ms. Sapna hooda (2011) a study of FDI and Indian Economy; Doctor of philosophy from national institute of technology (deemed university) Haryana. 